\title{
PERSPEKTIF KEPEMIMPINAN TRANSFORMASIONAL TERHADAP KINERJA STAF ADMINISTRASI PADA UNIVERSITAS ISLAM MAKASSAR
}

\author{
MULIATI, ERNAWATI \\ Fakultas Ilmu Sosial dan Politik \\ Universitas Islam Makassar \\ Email : muliati@uim-makassar.ac.id, ernawati.dty@uim-makassar.ac.id
}

\begin{abstract}
:
Transformational leadership has a positive and significant effect on the performance of Administrative Staff. Human resources or employees must always be considered, maintained, and maintained, and developed by the organization. Therefore, the administrative staff is valuable assets owned by tertiary institutions in carrying out institutional duties based on the tri dharma of tertiary institutions. Descriptive research was conducted by interview and questionnaire distribution, while the Transformational Leadership variable with indicators of Idealized influence, Inspirational motivation, Intellectual Stimulation, and Individualized consideration or individualized attention, all had gone well.
\end{abstract}

Keywords : the influence of ideas, motivational inspiration, intellectual stimulation, individual consideration

\section{PENDAHULUAN}

Sebagai bagian dari organisasi, kepemimpinan ikut memengaruhi komitmen melalui hubungan antara atasan dengan bawahan antara pegawai dengan pemimpinnya (Meyer \& Allen, 1997). Gaya kepemimpinan dijelaskan sebagai suatu proses, perilaku atau hubungan yang membentuk pola tertentu yang menyebabkan suatu kelompok untuk bertindak secara bersama-sama atau bekerja sama sesuai dengan aturan dan atau tujuan bersama (Sarwono 1999).

Permasalahan yang sering muncul di kalangan civitas akademika khususnya para staf administrasi yaitu mengenai harapan yang mereka peroleh sebagai sumber kehidupan masa depan mereka. Terkait dengan masalah ini adalah komitmen kepemimpinan organisasi yang memotivasi sehingga terbangun dalam pikiran staf bahwa bekerja di Lembaga pendidikan adalah pengabdian kepada Umat. Hal ini kemudian sering menjadi dilematis dalam melakukan pekerjaan pelayanan akademika.

\section{METODE PENELITIAN}

\section{Pendekatan Penelitian}

Pendekatan penelitian yang digunakan adalah pendekatan kuantitatif. 
Pendekatan kuantitatif berusaha mencari penjelasan hubungan antara variabelvariabel yang diteliti. Berpijak pada pendekatan kuantitatif di atas maka metode penelitian yang digunakan adalah analisis deskriptif, yang bertujuan untuk menjelaskan atau mendiskripsikan lebih jauh pola hubungan korelasi, keterkaitan antara dua atau lebih variabel yang diteliti.

Penelitian ini termasuk penelitian penjelasan (eksplanatory research), yang menganalisis pengaruh Kepemimpinaan transformasional, terhadap kinerja Staf administrasi Universitas Islam Makassar. Penelitian dilakukan pada Kampus Universitas Islam Makassar. Metode yang digunakan adalah survei dengan kuesinoer terstruktur atas sampel pegaai yang mewakili populasi. Responden yang diambil sampel adalah Staf Administrasi Universitas Islam Makassar.

Populasi adalah wilayah generalisasi yang terdiri atas: obyek/subyek yang mempunyai kualitas dan karakteristik tertentu yang ditetapkan oleh peneliti untuk dipelajari kemudian ditarik kesimpulannya (Sugiyono, 2008: 80). Populasi yang digunakan dalam penelitian ini adalah seluruh Staf administrasi Universitas Islam Makassar, yang berjumlah 63 orang.

\section{PEMBAHASAN}

Variabel kepemimpinan transformatif terdiri dari empat indikator dengan 8 pertanyaan. Pada pernyataan pertama, Pemimpin saya seorang visioner yang selalu mengutamakan kepentingan organisasi. Responden yang menjawab sangat setuju sebanyak 15 responden atau 23,8\%, jawaban setuju sebanyak 33 responden atau $52,4 \%$, responden yang tiak setuju hanya sebanyak 5 responden atau 7,9\%, dan jawaban terendah sebanyak 2 responden atau 3,2\%, dengan nilai mean sebesar 3,85. Hal ini berarti bahwa kriteria jawaban respnden pada variabel X1 termasuk dalam kategori baik.

Selanjutnya pada pertanyaan kedua, Pemimpin saya sangat paham dengan kebutuhan organisasi dan bawahan. Responden yang menjawab sangat setuju sebanyak 18 responden atau $28,6 \%$, responden yang menjawab setuju sebanyak 27 responden atau 42,9\%, 14 responden netral, dan sebanyak 4 responden yang tidak setuju atau 6,3\%. Dengan nilai mean sebesar 3,93 termasuk dalam kategori baik.

Pada pernyataan ketiga Pemimpin saya adalah mtivator yang selalu memberikan spirit kepada bawahan tentang visi organisasi yang harus dijalankan. Responden yang menjawab sangat setuju sebanyak 16 responden atau 25,4\%, jawaban setuju sebanyak 34 atau 54,0\%, responden yang menjawab netral sebanyak 11 atau $17,5 \%$, dan yang menjawab tiak setuju hanya 2 responden atau 3,2\% dengan nilai mean sebesar 4,01 termasuk dalam kategori sangat baik.

Selanjutnya pada pertanyaan keempat Pemimpin harus memahami kendalakendala teknis dan memiliki pandangan objektif, demokratis dalam melihat 
berbagai permasalahan. Responden dengan jawaban sangat setuju sebanyak 21 orang atau 33,3\%, jawaban setuju sebanyak 28 responden atau 44,4\%, responden yang menjawab netral sebanyak 12 responden atau $19,0 \%$, dan responden yang tidak setuju sebanyak 2 responden atau 3,2\%, dengan nilai rata-arata sebesar 4,07, dengan kategori sangat baik.

Sementara itu pada pernyataan kelima dengan pertanyaan Pemimpin saya memiliki kemampuan menejerial yang baik dalam mendorong kreativitas bawahannya. Responden yang menjawab sangat setuju sebanyak 13 responden atau 20,6\%, jawaban setuju sebanyak 33 responden atau 52,4\%, 15 responden dengan jawaban netral, dan hanya 2 responden yang tidak setuju, dengan nilai mean sebesar 3,90, yang berarti bahwa pertanyaan ini berkategori sangat baik.

Pada pertanyaan keenam Pemimpin harus menerima pendapat bawahannya. Responden dengan jawaban sangat setuju sebanyak 17 responden atau 27,0\%, responden yang menjawab setuju sebaanyak 33 responden atau $52,4 \%$, dan jawaban terendah sebanyak 1 responden atau 1,6\%, dengan nilai mean 4,15 berkategori sangat baik. Hal ini berarti bahwa pemimpin di Unversitas Islam Makassar sudah sangat demokratis.

Selanjutnya pada pertanyaan ketujuh dengan pernyataan Pemimpin hadir ketika pengikut membutuhkan, pimpinan ini bertindak sebagai mentor, mendengar apa yang menjadi perhatian dan kebutuhan pengikut, termasuk kebutuhan dihormati dan menghargai kontribusi individual terhadap organisasi. Responden dengan jawaban sangat setuju sebanyak 15 respondnen atau $23,8 \%$, jawaban setuju sebanyak 30 responden atau 47,6\% dan jawaban tidak setuju sebanyak 3 responden atau 4,8\%, dengan nilai mean sebesar 3,90 sangat baik. Pada pernyataan kedelapan dengan pernyataan Pemimpinan saya selalu Mengidentifikasi kemampuan pegawai, memberi kesempatan belajar, dan mendelegasikan wewnang; Responden dengan jawaban tertinggi sebanyak 15 responden atau 23,8\%, 35 responden atau 55,6 setuju, dan 3 responden yang tidak setuju dengan pernyataan ini, dengan nilai mean sebesar 3,98 atau sangat baik kategorinya.

Kemudian terkait kinerja responden. Pada pernyataan pertama, Saya mampu menyelesaikan pekerjaan yang lebih banyak dari standart. Responden yang menjawab sangat setuju sebanyak 14 responden atau 22,2,\%, jawaban setuju sebanyak 33 responden atau 49,2\%, responden yang tidak setuju, sebanyak 2 orang dengan nilai mean sebesar 3,93 daan termasuk dalam kategori sangat baik.

Selanjutnya pada pertanyaan kedua, Pekerjaan yang saya hasilkan sesuai dengan target yang telah ditetapkan perusahaan. Responden yang menjawab sangat setuju sebanyak 26 responden atau $41,3 \%$, responden yang menjawab setuju sebanyak 31 responden atau 49,2\%, 5 responden netral, dan sebanyak 2 responden 
yang tidak setuju atau 3,2\%. Dengan nilai mean sebesar 4,30 termasuk dalam kategori baik.

Pada pernyataan ketiga Saya dapat menyelesaikan setiap pekerjaan dengan teliti dan rapi.. Responden yang menjawab sangat setuju sebanyak 25 responden atau 39,7\%, jawaban setuju sebanyak 32 atau 50,8\%, responden yang menjawab netral sebanyak 5 atau 7,9\%, dan tidak setuju 1 orang, dengan nilai mean sebesar 4,28 termasuk dalam kategori sangat baik.

Selanjutnya pada pertanyaan keempat Saya mampu menyelesaikan pekerjaan yang lebih baik dari standart. Responden dengan jawaban sangat setuju sebanyak 18 orang atau 28,6\%, jawaban setuju sebanyak 39 responden atau 61,9\%, dan jawaban tidak setuju sebanyak 2 resonden dengan nilai rata-arata sebesar 4,15, dengan kategori sangat baik.

Sementara itu pada pernyataan kelima dengan Organisasi memberikan insentif kepada pegawai. Responden yang menjawab sangat setuju sebanyak 22 responden atau 34,9\%, jawaban setuju sebanyak 34 responden atau 54,0\%, 19 responden dengan jawaban netral, dan hanya 1 responden yang tidak setuju, dengan nilai mean sebesar 4,22 yang berarti bahwa pertanyaan ini berkategori sangat baik.

Pada pertanyaan keenam Saya mampu menyelesaikan pekerjaan yang menjadi tanggung jawab saya sesuai dengan yang ditentukan. Responden dengan jawaban sangat setuju sebanyak 16 responden atau 25,4\%, responden yang menjawab setuju sebaanyak 34 responden atau $54,0 \%$, responden yang tidak setuju sebanyak 2 orang dengan nilai mean 4,01 berkategori sangat baik.

Selanjutnya pada pertanyaan ketujuh dengan pernyataan Saya tidak pernah terlambat masuk kerja., Responden dengan jawaban sangat setuju sebanyak 14 respondnen atau 22,2\%, jawaban setuju sebanyak 33 responden atau 52,4\% dan jawaban netral sebanyak 14 responden atau 22,2\%, responden yang tidak setuju sebanyak 2 responden atau 3,2\% dengan nilai mean sebesar 3,93 sangat baik.

Pada pernyataan kedelapan Saya masuk dan pulang kerja sesuai dengan waktu yang ditentukan oleh Organisasi; Responden dengan jawaban tertinggi sebanyak 26 responden atau 41,3\%, responden yang setuju sebanyak 31 responden atau 49,2\%, dan 1 responden yang tidak setuju, dengan nilai mean sebesar 4,30 atau termasuk dalam kategori sangat baik. Selanjutnya pada pernyataan kesembilan Saya mengutamakan kerja sama dengan rekan kerja dalam menyelesaikan pekerjaan. Responden dengan jawaban sangat setuju sebanyak 25 responden atau 39,7 dan jawaban setuju sebanyak 32 responden atau 50,8\%. Dan 1 responden yang tidak setuju, dengan nilai mean 4,28. Pernyataan Kesepuluh Saya sering melakukan koordinasi dengan rekan kerja dalam menyelesaikan tugas bersama. Responden dengan jawaban sangat setuju sebanyak 18 responden atau 28,6\%, responden dengan jawaban setuju sebanyak 39 responden atau $61,9 \%$ dan jawaban 
netral 4 responden atau $6,3 \%$ dan jawaban tidak setuju sebanyak 2 orang dengan nilai mean sebesar 4,15 .

\section{Pengaruh Variable Independent (X) terhadap Variabel Dependent Kepemimpinan Transformasional (X1)}

Berdasarkan hasil olahan SPSS, maka dapat dikatakan bahwa Variabel Kepemimpinan transformasional (X1) berpengaruh secara positif terhadap Kinerja Staf Administrasi (Y) Universitas Islam Makassar. Nilai koefisien regresi sebesar 0,284 menyatakan bahwa setiap terjadi peningkatan dalam nilai kepemimpinan akan meningkatkan Kinerja Staf Administrasi Universitas Islam Makassar sebesar 28,4 .

Untuk selanjutnya besaran pengaruh tersebut dapat dilakukan dengan uji $\mathrm{t}$ untuk menentukan apakah pengaruh Kepemimpinan tersebut signifikan atau tidak. Dengan asumsi di bawah ini:

Jika $t_{\text {hitung }}>\mathrm{t}_{\text {tabel }}$ : Ho ditolak atau $\mathrm{H} 1$ diterima

Berdasarkan asumsi diatas, maka diketahui $t_{\text {hitung }}>t_{\text {tabel }}$ yaitu $2.780>1,671$, dengan tingkat signifikan $0,007<\mathrm{a} 0,05$. Hal ini menunjukkan bahwa variabel Kepemimpinan Transformasional berpengaruh secara signifikan terhadap Kinerja Staf Administrasi Universitas Islam Makassar.

\section{Pengaruh Kepemimpinan Transformasional terhadap kinerja Staf Adminstrasi Universitas Islam Makassar.}

Variabel Kepemimpinan Transformasional dalam penelitian ini memiliki tingkat signifikan yang tinggi yaitu 0,007 dengan nilai uji parsial atau uji t sebesar $2.780>1,671$ dari t tabel, dan nilai koefisien sebesar 0,284 atau tingkat pengaruhnya sebesar $28,4 \%$ terhadap kinerja. Dengan melihat hasil pengolahan data kuisener tersebut maka Kepemimpinan Transformasional yang ada di Universitas Islam Makassar pada umumnya sudah semakin baik, hal ini dilihat dari nilai mean masing-masing indikator dalam kuisener. Dimana dari 8 pertanyaan kesemuanya memiliki nilai Mean sangat baik. Dalam hasil wawancara dan hasil tabulasi jawaban kuisener, dapat diketahui bahwa variabel Kepemimpinan Transformasional dengan indikator Idealized influence (pengaruh idea), Inspirational motivation (motivasi inspirasi), Intellectual stimulation (stimulasi intelektual), dan Individualized concideration or individualized attention (pertimbangan individu.), semua sudah berjalan dengan baik.

Dengan hasil ini maka, penelitian ini sejalan dengan pendapat Bass (1985) 
dalam Yukl (2013, p.313) bahwa kepemimpinan transformasional adalah suatu keadaan dimana para pengikut dari seorang pemimpin transformasional merasa adanya kepercayaan, kekaguman, kesetiaan, dan hormat terhadap pemimpin tersebut, dan mereka termotivasi untuk melakukan lebih dari pada yang awalnya diharapkan mereka. Pemimpin tersebut mentransformasi dan memotivasi para pengikut dengan cara membuat mereka lebih sadar mengenai pentingnya hasil hasil suatu pekerjaan, mendorong mereka untuk lebih mementingkan organisasi atau tim daripada kepentingan diri sendiri, dan mengaktifkan kebutuhan kebutuhan mereka pada yang lebih tinggi.

\section{SIMPULAN}

Kepemimpinan Transformasional berpengaruh positif dan signifikan terhadap kinerja Staf Administrasi. Hal ini ditunjukkan dengan tingkat signifikasinya 0,0027 dengan nilai koefesien 0,284 atau 28,4. Temuan ini mengindikasikan bahwa makin baik gaya kepemimpinan transformasional menyebabkan makin tinggi pula kinerja staf administrasi dalam melaksanakan pekerjaannya.

\section{DAFTAR PUSTAKA}

Allen, N. J. \& J. P. Meyer. 1997.Commitment in The Workplace Theory Research Amir Sadeghi, ZaidatolAkmaliah Lope Pihie,(2013)The Role of Transformational Leadership Style in Enhancing Lecturers'Job Satisfaction.

Amstrong. (2003), The art of HRD: Strategic Human Resource Management a Guide and ApplicationCalifotnia: Sage Publications.

Andreas, Lako. 2004. Kepemimpinan dan Kinerja Organisasi Isu Teori dan Solusi, Yogyakarta, Amara Books.

Andrew F. Sikula (2009) Public Personnel Management;Compensasition strategicall

Anoraga, Pandji. (2003). Psikologi Kepemimpinan. Jakarta: Rineka Cipta Avolio, B.J. \& Bass, B.M. (1994). Individual Consideration Viewed at Multiple Levels of Analysis : A Multilevel Framwork for Examining Te Diffusio of Transformational Leadership. Journal of Leadership Quarterly.6(2),199218.

Bass, B.M. (1997). Does Transactional-Transformational Leadership Paradigm Transcend Organizational and National Boundaries?. Journal American Psychologist. 52:130-139.

Bass, B.M., Avolio, B.J. (1994). Improving Organizational Effectiveness through

Transformasional Leadership.Thousand Oaks : Sage.

Bass, Bernard M, dan Riggio, Ronald E, 2005, Transformasional Leadership. 
Berry, L.M., Houston, J.P. (1993). Psychology at Work. An Introduction to Industrial and Organizational Psychology. New York : McGraw-Hill International.

Bolden, R., Gosling, J., Marturano, A. and Dennison, P. (2003). A Review of Leadership Theory and Competency Frameworks. Centre for Leadership Studies, UK : University of Exeter.

Brahmasari, Ida Ayu dan Agus Suprayetno. 2008. Pengaruh Motivasi Kerja, Kepemimpinan, dan Budaya Organisasi Terhadap Kepuasan Kerja Karyawan serta Dampaknya pada Kinerja Perusahaan (Studi kasus pada PT. Pei Hei International Wiratama Indonesia). Jurnal Manajemen dan Kewirausahaan. Vol. 10, September: 124-135.

Burns, J.M. (1978). Leadership. New York : Harper \& Row.

Colquitt, Jason A., Jeffery A. LePine, and Michael J. Wesson. Organizational Behavior. New York: McGraw-Hill, 2011.

Dessler, Gary., (1997), Manajemen Sumber Daya Manusia, PT. Prenhallindo, Jakarta.

Dubrin, Andrew J. 2005. Leadership(Terjemahan). Edisi Kedua. Prenada Media. Jakarta.

George, Jennifer M. and Gareth R. Jones, Understanding and Managing

Organizational Behavior, 4th Edition, Prentice Hall, New Jersey, 2008.

Handoko, T. Hani (2000), Manajemen Personalia dan Sumber Daya Manusia Hartiti, T. (2013). Peningkatan softskill perawat melalui kepemimpinan tranformasional kepala ruang. Jurnal manajemen keperawatan

Hasibuan, Malayu S.P. (2009). Manajemen Sumber Daya Manusia (Edisi Revisi). Jakarta: Bumi Aksara.

Hasibuan, Malayu S.P. 2009. Manajemen: Dasar, Pengertian, dan Masalah Edisi Revisi. Jakarta : Bumi Aksara

Hasibuan, Malayu S.P. 2011. Manajemen Sumber Daya Manusia Edisi Revisi Hay, I. 2004. Transformasional Leadership: Charakteristic and Criticisme, School Herman Sofyandi, 2008, Manajemen Sumber Daya Manusia, Edisi Pertama, Penerbit Graha Ilmu, Yogyakarta.

Buku Risalah Bismillah, Membangun Generasi Khaira Ummah, Bag. 4, hal. 23-24) https://ybw-sa.org/2016/11/kepemimpinan-dalam-islam/ diakses tanggal 20 Mei 2020

J Antonakis, BJ Avolio, N Sivasubramaniam (2003)- The leadership quarterly,2003Context and leadership: an examination of the nine-factor full-range leadership theory using the Multifactor Leadership Questionnaire 
Jewell. L. N. \& Siegal. M. (1998).Contemporary Industrial and Organizational

Kendra Cherry (2013), What Is Transformational Leadership? How Transformational Leadership Inspire About.com Guide, retrieved Feb 5 2017 kinerja perusahaan (editor Deddy Mulyana, MA, Ph.D.), PT Remaja Rosdakarya Bandung 2006

Locke, E.A., 1997, Esensi Kepemimpinan (Terjemahan), Jakarta, Mitra Utama.

Mathis, Robert L, and Jhon H. Jackson, 2000.Human Resource Management10th Edition, Tomson South-Western, United States.

Michael Fullan, 2001., Leading In Culture Of Change, Jossey-Bass:San Francisco. Mowday, R.T., Porter LW., dan Steers, R.M., 1979, Employee-Organizational Linkages : The Psychology Of Commitment, Absenteeism And Turnover: Academic Press, New York.New Jersey : Lawrance Erlbawn Associates, Publishers.

O’Leary, Elizabeth. 2001. Kepemimpinan. Edisi Pertama. Yogyakarta : Andi. of Geography, population and Environmental. Management Flinders University (Online). Available: www. weleadin learning.com Perusahaan, BPFE, Yogyakarta. Psychology. USA: West Publishing Comp.Questia Online research. International Journal \& Mananegement Analysis; Illionscity.

Rees, Erik. (2001). Seven Principles of Transformational Leadership: Creating A Synergy of Energy. Diakses pada March 6, 2015, dari http://cicministry.org/commentary/issue 85 warren article. pdf.

Rivai, Veithzal. 2005, Kepemimpinan dan Perilaku Organisasi, Edisi Kedua, PT Raja Grafindo Persada, Jakarta.

Rivai, Verthzal 2006.Manajemen Sumber Daya Manusia Untuk Perusahaan: Dari Teori ke Praktik, Edisi pertama.Jakarta:Pt. Raja Grafindo Persada,

Simamora, Henry, 2004. Manajemen Sumber Daya Manusia. Yogyakarta : STIE YKPN.

Sudarmanto. (2009.) Kinerja dan Pengembangan Kompetensi SDM. Yogyakarta: Pustaka Pelajar.

Sugiono. 2012. Metodologi Penelitian Bisnis Cetakan Ke 2. PT. Refika Aditama. to Action Manajemen Sumber Daya Manusia Strategik Panduan Praktis untukbertindak, alih bahasa oleh Ati cahayani.Jakarta: PT Gramedia

Veithzal Rivai, 2004, "Manajemen Sumber Daya Manusia Untuk Perusahaan, Cetakan Pertama, Jakarta, PT. Raja Grafindo Persada.

Werther, William B. \& Keith Davis. 2004:52. Human Resources And Personal Management. International Edition. McGraw-Hiil, Inc., USA.

Wibowo. 2012. Manajemen Kinerja Edisi III. Jakarta.PT Raja Grafindo Persada Wursanto,2002, Manajemen, Cetakan Ketiga, Bumi Aksara, Jakarta. 
Yammarino, F. J., \& Bass, B. M. (1990). Long-term forecasting of transformational leadership and its effects among naval officers: Some preliminary findings. In K. E. Clark \& M. B. Clark (Eds.), Measures of leadership(pp. 151-169). West Orange, NJ: Leadership Library of America.

Yammarino, F. J., Spangler, W. D., \& Dubinsky, A. J. (1998). Transformational and contingent reward leadership: Individual, dyad, and group levels of analysis. Leadership Quarterly, 9, 27-54.

Yukl, Gary, 2010, Kepemimpinan dalam Organisasi, Edisi Kelima. Jakarta: PT. Indeks.

Yulk, G. (1998). Kepemimpinan dalam Organisasi. Edisi Bahasa Indonesia dari Leaership in Organizations.Jakarta: Prenhallindo

Siagian, S. P. (1995). "Pengembangan sumber daya manusia." Jakarta: PT. Gunung Agung. 